
100 a 29 


$$
582.35(68) \text { 触 }
$$

BuC. 



\title{
REVISED LIST
}

\author{
OF THE
}

\section{FERNS OF NATAL,}

EI

REV. JOHN BUCHANAN, A.MI.

K

REPRINTED FROM THE "NATAL COLONIST."

NATAL :

P. DAYIS AYD SONS, DURBIX AND MIRITZILRG.

1875 . 



\section{PREF A C E.}

Tire Rer. Mr. Buchianan, having kindly complied with our request that he should prepatre a Revised List of Natal Forns, wo bcg to pretix to it, in lien of preface, the following letter. Although lcaring Sunth Africa, Mr. Buclannn's ardor in the pursuit is as great as ever, and he will not relinquish the study, to the elucidation of which. he has done so much. We are, therefore, not withont loopes that at no very distant date even this Rerised List may be cxtended and improved; meanwhilc, we can conficlently recummend it as it filithful manual for all who love Ferns, ur desire to help in tlic advancement of this branch of science.

— ED. N.C.

TO TIIE EDITOR OF TIIE NATAL COLONIST.

Sir,-Somewliat tardily, but with plcasure, I send you for publication the following Revised List of the lerins of Natal, as suggested by you in the Colonist three months ago. It is as correct, and as complete in cletails of lnbitats and localities as I enu well render it. Sinee the late Mr. MeKen published his deseriptire List, which, in its nomenclature and descriptive parts, was drawn from the first edition of Synopsis Filicum, Mr. Baker las bronglit out a new edition of that valuable work, with some alterations, and many additions. Moro recently, Lady Barkly has done good scrvice to Pteridology, by licr carefully 'Revised List of the Ferns of Sonth Africa,' and especially by her minute record and interesting analysis of Capc localities. Not long ago, His Excelleney R. W. Rawson, Esq., Lieutenant-Governor of Barbadoes, kindly submitted to the inspection of Lady Barkly and myself his private collection of Soutli African Ferns, thereby furnishing a ready means of solving numerous difficulties in connexion with the Synopsis Filicum Africce Australis of Pappe and Rawson. All of these sources lave been drawn upon in the pre- 
paration of this Revision. With ne or two exceptions, the order followed and the names given are those of Syn. Fil., 2nd Edit. The Cape loealities are simply adopted from Lady Barkly. Some of the points ascertained fiom the Rawson Herbarium are specially mentioned; others are silently embodied. Since my leturn finm Umpumnlo, an examination of Dr. Kuhn's Filices Africance-(a marvel of eritical analysis and laborious diligence, ) - has raised sever'al questions, for the settlement of which I might have found means in that magnificent Natural Fernery, but which must now lic over. Some of these are indieated in the list, and brother-eollectors are invited to aid in secking their solution. Several Transvanl speeies are noted, and amateurs would do well to keep a lookout for them in our own northern distriets; but, doubtless there are many more yet undiseovered in that great countr's, perhaps in our own. In a small eollection, lately sent to Durban from the Gold Fields by Mr. T. Ayres, at least six speeies appear which I have never seen in Natal, and some of them never at all. Unfortunately norrly the whole of the Trans-ALooi and 'Trans-Umlazi portions of Natal are mnknown to me; and, consequently they are pretically ignored in this conpilation, for I have limited inyself to what I know rither from personal explorations or otherwise. But what is here given may prove a help to amateur's, and perhaps eneomage some brotherinvalids, medieally exiled like myself from ster'n offleial life, to try the remedial power's of freqnent rambles, portfolio in liand, over the braeing lieights and in the cool shady ravines of om charming mplands. Finally, let it be muderstood that, as the findings of brother-eollectors are embodicd lore along with my own, the first person plural of this Revised list is emplozed legitimately, and not as it mere editorial conventionalisn.

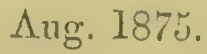

JOHN BUCIINAN. 


\section{THE FERNS OF NATAL.}

REVISED LIST, 1875.

\section{GLEICIIENIA.}

1.-G. polypodioides, Sm. On rocks and moist banks; often in large pendulous masses: Kranskloof; Inanda ; Noodsberg; Umpumulo; Maritzburg Tuwnhill; fine in a diteh at Padlcy's; Magalisber'g, and throughout South Africa to Angola.-M.

G. argenteu, Klf. (G. gluuea, Sw.,) a Cape plant, is only a variety.

2.-G. (Mertensia) umbraculifera, Moore; (Mtert. umbiruculiferu, Kze.) On moist open slopes; usually in extensire beds about the upper margins of bush, 2,000-3,000ft. abore sea; behind Half-rray Honse; Noodsberg; Umpumulo; Greytuwn; 'L'owu-hill of Maritzburg; Riehmond; abounds on Drakensberg at Cathkin ; Kaftaria - U.M.

3.-G. (Mertensia) dichotoma, Willd.; (Mert. dichotoma, Kze, Mesosorus, Hassk.) Diseovered 1874 at Umpumulo, on a moist open slope, freing the south, in bush, near the top of a hill, two miles W. by S. of the Mission Station, about 2,500ft. elevation; throughout the Tropies. $-\mathbf{M}$.

\section{CYATHEA.}

4.-C. Dregei, Kze. A tree-fern, common in open places near water, from Westrille to the Drakensberg; Kafraria to the Zambezi.-N.

C. Burkei, Hls., in the Transvaal, is a mere variety. IIEMITELIA.

5.-II. (Amphieosmiu) Capensis, R. Br.; (Amplic. ripariu, Gardn. Alsophila Capensis, J. Sm., Aspidium, Sw.) An elegant treo-fern, eommon in the Cape, found in Natal only by streamlets in bush. In the range of hills extending from the Inanda to Umpumulo, 2,000-3,00nft. above sea. Occurs also on Town-hill of Mrtzburg; Mauritius, Comoro Islands, Jara, Brazil.-Iil.

$$
\text { WOOODSL. }
$$

6.-W. (Physematium) Burgessiana, Gerr. Roeks; at Liddesdale; Nottingham; Lynedoeh; Karkloof; 
Mount West; and rery fine under projecting masses of rock on Drakensberg at Catblin; E. Prov. Capc, and Transraal.-U.

\section{IIYMEYOPII LLUM.}

7.-H. rarum, R. Br.: (H. Natalense and tabulare, T.1D.B., H. flabellatum, Klf., II. fumarioides, Willd.) Habitat unknown to us, but gathered in the Colony by the late Mr. Gncinzius; thronghout South Africa, 'I'asmania, N. Zcaland, Auckland Islands.

8.-II. gracile, Bory; ( $H$. incquale, Desr) Habitat unkuown to us, but Mr. Bakcr has detected the plant in the Rawson Herbarium, labelled by Mr. Sanderson of Nital as Trichomanes Filienla; perhans gathered in 'T'rmsraal. It is found in the Mascarene Islands.

[1L. lincare, Sw.; (H. pendulum, Bory: H. elegans, Slu.; II. trifidum. Hk. and Gr.) Recently gathered by Mr. A yres at Macmac Goldficlds; probably to be found also in Upper Natal: Mauritius and 'Tropical Ancrici.]

9.-II. Tunbridgense, Sm.; (Leptocionium T.D.B.) On damp rocks and old trecs: Kransli]oof; Maritzburg 'Town-hill; Noodsberg; Umpumulo, and Karkloof; throughout S. Africa. Cosmopolitan.-M.U.

9a.-II. TIrisoni, Hk.; (Ir. pellutum, Desr; II. unituterale, Bory; II. Meyeri, Pr.) Reckoned a raricty of the forcgoing at Kew, but a distinct species by Kuhn; scems to occur pretty much in the vicinity of IT. Tiunbridgense, in Natal, as it does clscwherc.-MI.U. TRICHOMANES.

10.-7. pusillum, Sw., var. quereifulium Hk. and Gr. On damp rocks and old trecs; Kranskloof; Noodsberg; Umpumulo; Maritzburg 'Town-hill, and Nottingham; Tropical America. Kuhn gires our plant as Trieh. reptens, Mctt. rav. mejor, Mett., holicring it to be 'sufficicntly different from an average slecincu of Trich. musillum, Sw., from the Antilles,' to rank as a distinct species, and assigning it to Crntral and S. Ameriea, as well as Natal.-M.U.

[1. Filirulu. Bory, has becn credited to the Cape? Colony and Natal, Imt, we beliere, withont good authority. Tady Barkly, like onlsclves, has nerex scen a specimen from rither distriet, and Kuln exclucles it from the African Contincnt. It is well known in the Nasca reno Lslands.]

11.-T: puricliferum, L. On damp rocks and old tress; from Ficld's Hill to Umpumulo. and thenee to the Urakensberg; thronghout S. Africa; also in 
Fernando Po, Hindostan, Moulmein, Borneo and N. Caledonia; common throughont Tropical America. Kuhn limits T. pyxidiferum, L., to IV.'I'ropical Afriea, Central and S. America, and considers our plant to be a distinct species, whieh be names $T$. melcunotrichum, Schl.. assigning it to the River Nun, the Cape, Natal, Bourbon, Mauritius, Comoro Islands and Asia.-U.M.

12. -T. rigidum, Sw. Usually found close to tiny rills of water, or on wet eaudices of tree-ferms; Kıanskloof; Umhlasine, Longsight; the Inanda; Great Noodsberg; highest bush of Umpumulo ; Attereliffe; not in Cape Colony, but throughout the Tro. pies; also in Japan and New Zealand.-M.

DATALLIA.

$[D$. elegans, $\mathrm{Sw} .$, as entered by $\mathrm{Mr}$. McKen, is the same as the following.]

13.-D. nitidula, Kze.; (Triehomanes chcerophytloides, Poir.) On trees in eonst bush, and at Kearsney; on roeks at Umzinyati Falls, Inanda. Kuhn gives it as $D$. denticulata, Mett. (D. eleguns, Sw.) var. intermedia, Met.t., and assigns it to Natal, Angola, W. Tropieal Afriea, Comoro and Seychelles Islands, and Madagascar. It has been gathered by Sir H. Barkly at St. John's River, Kafraria.-C.

14.-D. (Microlepia) spelunece, Baker; (Polypod. spelunca, L., Microl. spelunca, Moore, Microl. polypodivides, Pr.) In bush-swamp, head of Bay of Natal, and on an open but wet slope at the base of roeks $\mathrm{S}$. of Mission Station at Umpumulo, only; at Itshon, Zululand; Magalisberg; W. Trop. Africa, Seyehelles and MIasearene Islands, Trop. Asia and Polynesia, IV . Ind. to Brazil.-C.M.

15.-D. (Loxoscaphe) theeifera, H.B.K. : (D. cammyloptera, Kze., D. concinna, Sehr., Aspl. eoncinnum, Kuhn, Lox. concinum, Moore.) On trees, 2,500ft. elevation, and upwards: Richmond; Maritzburg'Tomnhill ; Umpumulo; Karkloof ; Nottingham ; and Cathkin; E. Pror., Cape; 'Lambezi, Abyssinia, Angola, Fernando Po, Bourbon, Andes of S. America.-U.

\section{CYSTOPTERIS.}

16. - C. firgitis, Bernll. In wet and shady plrees, from Greytorn to the Drakensberg. We have ncrer seen it under 3,000ft. elevation. E. Pror., Cape; and, generally, in temperate regions of the world, as well as high tropieal mountains.- $U$. 
LINDSAYA.

17.-I. (Schizoloma) ensifolia, Sw.; (L. lancelata, Labill., Schiz. ensifolia. Sw.) Streamlets; near New Guelderland, Kirkly Tale, and Lower Umroti ; Attercliffe: Cocdmore; and in bush-swamp, head of Bay of Aatal. In 'Tropics, from Guinea Coast eastward to Polynesia.-C.

\section{ADIANTUM.}

18.-A. renifurme, I., rar. A. asarifulium, Willd. Gathercd on the Drakcusberg, beside a spring. A plint of the Masc. Is.-U.

[A. cundulum, I. A plant well known throughout Trop. Africa and $A$ sin, bas been gathered in Transraal by Mr. Todd of Inanda, and is probably to be found in Upper Natal.]

19.-A. copillus Teneris, L. (the 'Maiden-hair' of Great Britain.) Moist locks and banks; common aloug the coast; frequent up to $2,000 \mathrm{ft}$, afterwards more rare; fine at Kark loof rills. Cosmopolitan.-N.

20.-A. AElhiopicum, L. In the drier parts of bush; conmon from Maritzburg and Karkloof to the Drakensberg. Iarcly exists at Umpumulo. In Spain, Abyssinia, W. 'Trop. and S. Africa, Masc. Islands, Neilgherries, Australia, N. Zealind, and nearly all America, Kuhn calls our plant $A$. thatictroides Willd., (A. 'renulum, Poir,) considering it to be a distinct species from $A$. Ailhiopicum. He finds the former throuehout Africa, the Masc. Istands, Asia and America; the latter only in the Cape, Natal, Cameroons and Australia.-U.

LONCHITIS.

21.-L. pubescens, Willd. Neal water in bush; Kranskloof; Umbilo Falls; Field's Hill ; Inauda ; Grt. Noodsberg; Umpumulo; Cape, IV. Trop. Africa, Masc. and Seych. Islands. Kuhn malies thee species, viz., (1) Pleris glabra, Mett., (L. glabra, Jory,) in Natal, the Cape and Bonrluon, (2) J'(cris Nutulensis, Kuhn, (L. Nutalensis, P. \& K.), in Natal, and Johumna Islands. (3) Plevis jubesecns, Kuln, (L. pubescens, Willd., L. hirsula, Bory, in Masc. Islands only. Baker consider's that these all form but one variable species.-MI.

\section{HYIOLEPIS.}

22.-II. unlluiscifuliu, Pr.; (H. aspera, Pr., Cheilanthes aspere, Kif., Cheil. commutatu, Kze., IIypulepis sparsisora, Kului.) Open but shelterod places beside 
water ; Umbilo Falls; Field's Hill; Inanda; Great Noodsberg; Naritzburg Town-hill; and Umpumulo: throughout S. Africn, and at Fernando Po.-M.

23.-7I. Bergiana, Hk.: (Cheilanthes Bergiana, Schl., Ch. elala, Kzo., IIyp elata, Pr.) Dricr parts of bnsh. 2,00ก-3,000ft. eleration : Maritzburg Town-hill ; Fort Buckingham; Umpumulo; Esidumbeni; and rery finc at Kruisfontcin, close to the high road: throughout S. Africa; Zambeziland.-M.

\section{CIIEILANTUES.}

24.-C. (Adiantopsis) pteroides, Sw.; (Atiantum pleroides, L., Cassebeera, Pr, Adiantopsis, Fée.) Habitat uuknown. Collected in Natal by Gueinzius, teste Kubn. Table Mountain, Cape; Orange Free State; Jara.

25.-C. (Adiunt.) Capensis, Srv.; (Adiuntum. Capense, Thbg., A. marginatum, Solir., Cheil. pretexta, Klf.) In rocky scrub on Eland's Kop, MIooi River, only; 5,000ft. abore sea. Common near Capetown, and in many parts of Cape Colony.-U.

26.-C. hirta, Sw.; (C. glandulosa, P. \& R., C. contracta, Kze., C. comuta, Kze., cx parte.) Dry rocky places, and in bush; common over the Colony, and orer all South Africa; Bourbon. Kunze makes four varieties, viz., contructe, intermediu (our coast rinriety,) laxa, and parvitoba (in our upland bush.) $-\mathrm{N}$.

27.-C. multifida, Sw.; (Adiantum, Schr., Allosorus, Bernb.) About rocks: Field's Hill; Intshanga; Inanda; Noodsberg; Umpumulo; Cathlin; rery fine near Insusi Falls; 1,000-1,000ft.: throughout S. Africn, to St. Helena and Zambeziland. Jara.-M.U.

PELL巫A.

28.-P. (Cheiloplecton) auriculata. Féc: (Cheilunthes auriculatu. Link, Allosorus. Pr., Pteris, Sw. Adiantum, Thbg.) Habitat nuknown to us; but gathered in Natal by Kranss, teste Knhn. Table Mountain, and Nitchell's Pass in Cape Col.; Namaqualand (Sir IT Barkly.)

29.-P. (Cheilop.) geraniifolia, Féc; (Pteris, Raddi fil., Pt. concolor, L. \& F., Pt. Pohlicene, Pr., Pt. pellute, P. \& R., rlecilanthes Kirkii, Hk.) Dry parts of bush: Palmict; Umbilo; Kranskloof; Inanda; Maritzburg Town-hill; Zwartkop; and Umpumulo: E. Pror., Cape: Angola, Zambezi, Mascnrene Lslands; thronghout the Tropies generally:C.M. 
50.-P. (Allosorys) pectinffurmis, Baker; (Pleris perlinifurmis, Kubn. J'illau duru. Hk. cix purie.) On busly-c.lad rocks noar Umzinyati Falls, Inanda, and in ererices of an isolated conical rocky hill at Killiecrankie. Found also by MIr. J. M. Wood at the bise of rucks on the Lmluluti, 1,000-3,000ft. abore sca, Angola, Comoro Islands, and Madaguscur. - M.

[P. (Allo.) Buirini, Hk.; (Pleris, Moore.) Magalisborc, and probably in Nintal too, but unknowa to us. Niasc. Is., Ceylon, S. India.]

31.-P. (Allo.) ronsobrina, Itk.; (Ploris quadri-

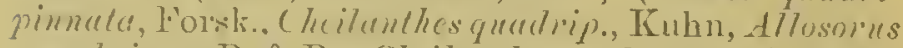
consulurinus. P. \& R, Cheilunthes Atherstoni. P.\& R., Ch. liangulu. Kzo, in whieh last Moore himsolf bas mereged lis $C h$. firmu and lincuris.) Opon banks and rocks: appenring at Tmpmmulo, Noodsberg, and Maritzburer 'l'own-lill, but luxuriating in Nottingham district; 3,000-1,(00)ft. above sea; throughont S. Africa; Camoroons, Mbyssinia, and Mlasc. Is.-U.

32.-P. (Allo) Bujeri, Hk.; (Ploris contruete, Mett., Cheil. conliactu, Kze, P'teris lasiopleris, Bojer, Cheil. comulu, L. \& R. ex purte.) In $s, n$. Fil. this is set down as a var. of $P$. consobrina, bnt it seens to $11 \mathrm{~s}$ to be more allied to $P$. hastula, Link. We are inclined with Kuln to regard it as a speeies distinct from buth. Abont rocks; Inanda ; Unpumulo; and Kínusliloof. Madagasciar.-M.

33.-P. (Pletyloma) hastate, Link ; (Plovis viridlis,

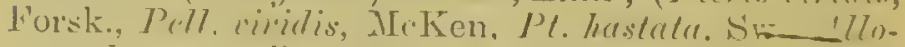
sorus hustulus, P'r., Cheilunthes, Kze.) In bush, and on open roels and banks, rarying much in size and cutting according to site. Common orer the Colony; in Cape, and, apparcntly, all Africa- $\mathbb{N}$.

[P. (Plaly) Teurumeles, Baker ; (Ploris, Mott) A plunt intermediate between Nos. 33 \& 3.t. Gatliered by $.1 \mathrm{r}$. IV. Todd of Inandir, in the 'I'mansraal. It is jrobably to be found also in North Niatal. Sonth Africa (Broutel).]

31.-P. (Plaly.) colomelanos, Link.; (Pleris calo-

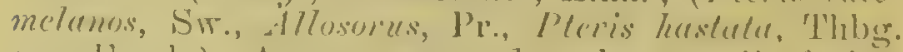
non liorsk) Among exposed rocks, nsmally ficing the sim; common from near the const to the Dria kensberir ; nplurently orer all Africa. Ilimalayas,M.U.

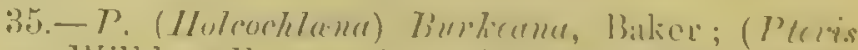
dlure, Willd., Allosous, l'r.) Driplpiner rockis ; (ircut 
Noodsberg, Inanda, and Umpnmulo. Transvaal, Angola, Mase. and Comoro Is.-M.

PTERIS.

36.-P. Tongifulia, I. ; (Pl. costutu, Bory, Pt. ensifuliu, $\mathrm{Sw}$.) Close by open ruming water, sparsely through the Colony. Very fine in the fumes of a hot sulphulous spring, Inhlimbiti, at 2,500ft. eleriation. Tropienl and warm temperate regions all round the world; but not in Cape Colony. $-N$.

ST.-P. Cretica, L. ; (Pt. serrariu, Srr.) Moist open banks, and drier parts of bush. Billely appears below Niapumulo Mission Station, at abont 1, shoft. elevation, but abonnds from Maritzbnirg Bush to the Drakensberg, 3,UUUft. and upwards.-U.

38.-P. quadriunritu. Retz.; (Pt. catoptere, Kzo) Ahout open stremlets in the lower parts of the Colony, and in the mnist bush of the mplands. Transraal; not in Cape.. . 11 round the world within the Tropics, and a little beyond them. (The usually aecurate Kuhn confounds this plant with P. biaurila, L. Sec below.) -N.

39.-P. Autsellata, Thbg.; ( $P$. argute ras. Autbellata, Kubn.) Neąl water in bush: over all the Colony from swamp at head of the Bay to the Diakensberg. From the Cape to Fermando l'o and Abyssinia : St. Helena and Ascension.-N.

40.-P. tremulu, R. Br.; (P. Caffiu in the Rawson IErbarium.) Discorered by $\mathrm{M}$. $\mathrm{r}$. Wrood near month of Umhloti Rirer, and grown by him in his garten at Iongsight, Inandid. Australia, 'I'ismunlit, and N. Zealand.-C.

4.1.-P. (Presia) aquilima, L.; (common 'bracken.') In the open, orer all the Colony. Cosmopolitan. - N.

[P. (Campteriu) biaurita, L. (Pt. nemoratis, Willd.:) A plant haring all the appearanec of the Tropical $P$. bicurilu. grows freely from Inanda to Tugcla, ringing about 20 to 30 miles from the ocenn and 2,0 noft. eleration. but it lias the free renation of $P$. quadricurilu, to which Mr. Balier joins it as a rariety. Perhaps this is the plant which Finhn guntes from P. \& R. ns P. celopleiv, Kzc., but which the Rarrson Herbarinm

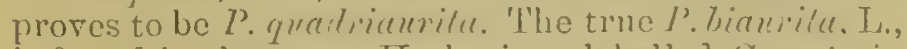
is found in the same Herbarium labelled Cumpleriu biauvilu; localiky unknown.] 
42.-P. (Campteria) Buchanani, Baker, MS. Discovered in a depression among the roeks at head of Intshanga eutting, where it grows to $7 \mathrm{ft}$. in height; also in Karkloof, and afterwards abundantly in the bush at Entumeni in Zululand; 3,000-4,000ft. elevation. It resembles $P$. flubelluta, but is distinguished by its campterioid renation, tripartite division, and mide-ereeping rhizome. It is probably the same as a plant from Kafraria in the Rawson Herbarium, bearing some five or six names (P. scrulata, Pappe, \&c.) ; and Lady Barkly names it as found at the Kuysna in Uape Colony. - M.U.

43.-P. (Litobrochia) incisa, Thbg. ; ( $P$. vespertilionis, Labill., $P$. glaucescens, Bory.) In wet parts of bush : Kranskloof́ and Inauda (rare); Noodsberg; Umpumulo (cormmon); abont 2,000-2,500ft. elevation. I'hroughout S. Afriea, and the Tropies all round the world. - M.

\section{LOMARIA.}

4t.-L. Tisqolor, Willd. rar. Nrtalensis, Baker. Beside open streamlets: Nottingham; Karkloof heights: and on the Jrakensberg at Cathkin, abundant. Not known in Cape. Austr., Tasm. and N. Zealaud.-U.

45.-L. attenuatu, Willd.; (T. gigantea, Klf., I. heterophyllu, Desv., L. decipiens, L'. \& R., Onoclea altenuala \& polypodioides SW., Blechnum polypo. dividles, Kunln.) Conmon, near running water, in the shade or open, over the Colony. All South Afrien, IV. 'Lrop. Afr., Masc. Is., 'I'rop. Ameriea and l'olynesia.-N.

46.-L. punctulata, Kze.; (Blechurm punet. Sw., L. auriculuta, Desv., I. unstralis, Lorre, and probably $L$. inflexa P. \& R., whieh Kuhn retains as a distinet speeies, but which Mr. Rawson 'does not know.') About rocks, from the Palniet to the Drakensherg. Common throughout So. Afriea. Java. Sometimes Blechuoid, and frequently much auricled. $-\mathrm{N}$.

46 a.-Scolopendrium. Trebsii, Kze. A remarkable variety of $L$. punetuluta, and itself very variable in venation, and in shape and position of sori, is found abundantly ahout wet rocks from I'atillo's, Ifrough Inanda and Noodsberg to Umpumulo, 1,500-2, jovit. abore sea. Cajue.-M. 
4.7.-L. morem. Spreng.; (Osmunda Capensis, L, Lom. Funensis, Willd., Blechnum ('apense. Seht, Lom. corll? "Desv) sitreantets, open or sharted: Atiercliffe; Field's-hill; Krantzkop; Inanda to Unp:mnulo; Greytown, to Richmond, 2.(14) 3).300ft. above seib. Thromerhout so. Africa. 'Trop. Amer, Malizy, and Polyn. Is, Anstr., 'l'asm, N. Zealand-M.

4s.-L. Boryuna. Willd ; (L. tabularis, Nert., Pleris. 'Thbre, islechnum labulare, Kuhn, Lom. Majellanica. Desi., L. D) Iguirmsice, P.\& R, L. eycadvides, P.\& R. the last being o ily an aurieled form, often to be met with amongst ordinary forms, where the growth is lnxmiant) Abont springs in open land : $2,001-3,(x)$ (f) above sea, from Bothas s-lill through Inandia to Umpummlo, from Greytown to Richmond, and all bew ween these lines. 'Throughont So. Africa. Angola, Mase Is.. W. Ind. to Straits of Magellan.-III.

BEECINUM.

49-B. Atherstoni, P. \& R, regarded at Kew as only a Bleehnoid rariety of Lom. punctulata, Kze., but retained by Kühn as a distinet speeies; and we are inelined to a gree with him. There is a Bleehnoid form of $L$ punetulatu, resembling the normal plant in size and texture, and srol. Krebsii is not nuch different in these respeets, whereas this plunt is large and coarse, of quite coriaceous texture, and indistinet venation, with a very tough stipes. It ha often a ereeping rhizome. The sori are usnally quite Blechnoid in the upper part of the frond; in the middle and lower parts, where the sori gradually draw away from the rachis to the tips of the pinnæ, the inner portion of the fructifieation is broken up into small dots, somerhat as in a Doodia. But in all eases the sori lie close to the midrib; nerer, as in Scol. Trebsii, midway towards or near to the margin. Its habitat is never, like the latter and $I$. punetulata, in wet places, but usually the eomparatively dry upper margins of bush. Inanda; Grt. Noodsberg (very fine); Umpumulo; Karkloof; near Grahamstown, Cape.-M.U.

50.-Blechum australe, I.; (B. rigidum, Sw., $B$. luastatum \& trieuspe, Klf., Lomaria pumila, P.\& R.) Rocks and shady banks; Greytown; Nottinghan; Cathkin; rery fine beside Iskoti, Little Noodsburg; 3,000-5,000ft. above sea. T'hroughout S. Africa. Mase. Is. (to which Inbn adds Asia \& So. Amer.) -U.MI. 
A.SPLENIUM.

51.-A. Kraussii. Moore; (A dentatum, P. \& R.) On shaded rocky banks, often in serub; at Rict Vlei; Mooi Rirer; and Nottingham. Found in unusual luxuriance at Nottingliam. sprarrling in large moss, at the roots of old trees. Graff-Reinet, Cape-U.

52 . - $A$ sandersoni. 11k. Moist rocks in bush, and old mossgrown trees; Field's-hill ; Longsiıht, Inanda (abundant in lavine in front of the house;) and rarely at Umpumulo, Grt. Noodsberg and Killiccrankic. 2.010tt. eleration. Amatola Mountains, Kafraria. Zambeziland, Johamna \& Mase. Is.-M.

53.-A. 'I'richomanes, L. ('Maidenhair Spleenwort.') Small bushy rarines, at Mooi Rirer only, 4,000ft. above sea. 'l'hroughout So. Africa, but by 110 means common. Temperate regions of the old world. from Britain and the Azores enstward to Japan and the Himalayas; So. Austr., 'l'asm., N. Zealand, sandwich Is.; N. Amer. and southward along the Andes to Peru.-U.

54.-A. monanthemum, L. Beside shady rirnlets; in all the uplands from Maritzburg 'Iown-hill and Karkloof to the Drakensberg, 3,000-5,000ft. 'T'hroughont So. Afriea. Abyssinia; Fernando Po; Cape Verde, Canary, Madeira and Azore Is.; Sandwich Is. : Mexieo along the Andes to Chili-U.

55.-A cbeneum, Ait. In small rocky serub, rare ; Riet Vlei, Mooi Rirer, Nottingham, and Seren-MileBush on the Unkomas, 4,000ft. abore sea. 'Through. nut So. Afriea. Cauada to the West Indies and Eenador.-U.

[In Syn. Fil. the next four names in our List; with their synonyms, ale all included in one, riz., $A$. lunulatum, Sw. Kubn distributes the same into seren species. Confessedly it is a group of plants as difficult to classify as it is wide in its distribution throurgh the world. Perhaps, if enlled upon to wado through and arrange such heaps of specimeus of these plants, from all parts of the wnrld. as those which crowided the table of the late Sir IV. Hooker, most I'teridologists would ecaso to wonder at his final lesolution to sweep them all away together into one compreliensire species. But, looking at our Natal represcntatives of the group alone, we find them arranging themselies casily and naturally muder four types. 'Ilrose forr are all found almuidantly in tho Colony, and at Umpumulo all mixal 
together in great luxurianee, yet erelywhere with distinetive features so marked. so numerons, and, withal, so constant, that we feel eonstrained to recognise their claim to rank as speeies. So far, we agree with Kuhn.]

$56-A$. lunulatum, Sw.; (A fulcatum, Thbg. A. regularc, Sw., A. Dolubellu, Kze.) Usnally near streamlets in bush; from the eoast to Uinpumulo and Maritzbnrg Town-hill. Cape, St. Helena, Bourbon; Asia and Ameriea - At Engeleni, on the eoast, we have seen a form of this with singularly flexible raehis, and proliferous apex, eovering a eonsiderable bank with as densely matted a turf as that of any stramberry bed. We hare nerer seen Nos. 57, 53 and 59 proliferous. $-\mathrm{N}$.

57.-A. Urachyotus, Kzo. More constantly beside water in bush than No. 56 but occupying the same section of the Colony, viz. from the coast to $3,000 \mathrm{ft}$. above sea. Cape. Asia. $-\mathrm{N}$.

58.-A. erectum, Bory, rar. harpcodes, Kze. All through bush in the upper parts of the Colony, from 2,000 to 5.1100ft abore sea. Cape. W. Trop. Africa.-U.M.

59.-A. gracile. P.\& R.; (A. lobatum. P.\& R.)-Natal is not eredited by P. \& R with this form, but we hare seen specinens of both forms, in the liawson Herba. rium, which are to us indistinguishable. Oeeupies the same district and much the same habitat as No. 58. Cape A.pulchrum, 'I'bonars, retained by Knhn as a species, is probably the same.-U.M.

59 a.-A. Zeyheri, P. \& R. A form whieh we hare seen only twice in Natal, riz, onee at Lynedoeh, and onee at Umpumulo; seems to be a rariety of $A$. gracile, perhaps a connecting link with No 56 . It seems to be the Aspl. polymorphum of Eekl. \& Zeyh. Cape.-U.M.

61).-A. Prionitis, Kze.; (A. obliquum, Willd.) Common in eoast bush, sometimes on trees. We have seen it as far inla id as Inanda, 1,500ft. abore the sea. E. Prov. Cape. Manritius and Bourbon $($ Kuhn $)-\mathrm{C}$.

$61-A$. anisophyllum, Kze. IVet or very damp parts of bush; Inanda to Umpumulo, and thenee by Fort Buekingham and Karkloof to Riehmond, 2,1000. 4,0) Net. Varies in shape and cutting. Kafraria. Cameroons, Zambezi, Bonrbou, Central and Soutb Ameriea.-M.U. 
62.-A. Serra, C. \& F, rar Vutulense, Baker. Under the rlip of water in bush; at sonthern terminus of Git Noodsberg, only ('ameroous and Fern. Po Tropical America.- M.

63. -A gemmifirum. Schr.; (1. Turidum, Schl.) Damp and haty places: Inanda; Unmmolo; Maritzburg 'J'own-hill; Richmond; Seren-Mile-Bush. From the Knysua to Natal. (Lady Barhly) Angola, Zambezi, Masc Is.-MI.U.

63a-A. flexno*um, Schr.; (A. Inciniutum. Nett., A. discolor, P. \& R.. A. lucirlmm. Sithl.) is only a divided form of the foregoing In Seren Mile-Bush and the adjoining . Happy Tralley, Upher Umkomis, 4.(10)ft abore sea. (ape, at Knysua, Philips. town, and Albany (Knhn.) - MI.U.

61. -A. protensum, : celır. By shariy streamlets, from Grt. Noodshere and Unjummlo to the Drakensberg, 2,1011.5.1010ft. From the Knysna to Natal. F'ern. P'o., Abyssinia, Mt. Kilimanjaro, and Mau. ritins. $-U$.

65.-A. Gucinziunum, Mett According to Kunhn, gatliered in Natal by Gucinzins; but plant aud habi. tat are unknown to ins

$66-A$. Adiuntum-nigrum, L ; (A. acutum. Bory, A. produclum, Lowe, A. serrulalum, ('ar. "Black Eplecnwort.') Rock' places nuder slight sbarle: Mapumulo: Grevtown; Riet Vlei; Mooi Rirer; Maritzburs 'Town luil. Common thronghont So. Afriez. From the Cape to Norway. and from the Azores to Siberia. Ilimalayis, Java, Sandwieh Is., Mase. Is., St Helena.-M U.

67.-A. eunculum, Lnm.; A. affine. Sehr.) In bush; nearly ererywhere from the Palmiet to Nottingham. E. Pror, Cape. Mozambiqne. Johanna and Seyeh. Is. 'T'rop. Amer. and Polynesia to Jara and Hong. kong.- N.

68.-A splendens, Kze. 'This is distinguished in $211 \mathrm{l}$ Ed. of $\forall n$. Fill. from $A$. cuncalum. Lam, with which it was formerly joined. We do not know it, although Natal is creclited with it; and we confess that we are puzzled to find the same work, which crowds our Nos. 56,57,58 and 59 into one specios, making out two speeies here. Kulun gives Kat River and Kafraria, as well as Natal, as loenlitics of this plant.

69.-A.furcalum. Thbg ; (A. pramorsum, Sw.. A. canamense, Willd.) Opent rocks, and in bush, often on trees; from Maritzburg 'Town-hill and Umpunulo 
to the Drakensberg, 2,500-5,000ft. Throughout So. Africa, and the Tropieal World, reaehing northward to Madeira, the Himalayas and Japan.-U.

69 a. - Var. tripinnatum, Baker, is only a luxuriant form found in rieh moist parts of bush at Nottingham, but not on trees. A singular elongated form is found in a limited loeality about Lynedoeh. (The tripinnate form was onee thought to be $A$. laserpitiifulium, Lam.)-U.

70.-A. varians, Hl. \& Gr.; (A. fimbriatum, Kze.) Moist shady rocks, and old trees; appearing at Umpumulo and Maritzburg Town-hill, but abounding about Nottingham and Cathkin, 2,500-5,000ft. E. Prov. Cape. Neilgherries and Himalayas.-U.M.

[A. bulbiferum, Forst., eredited to Natal in Syn. Fil. is probably a mistake. At all events it is unknown to us, and not in Fil. Afir.]

[A. cicutarium, Sir., a plant said to have been gathered by Mr. Sanderson in the Magalisberg, found also in Abyssinia and on the Guinea Coast, and abounding in 'Trop. Amel., is probably tho same as that formerly indieated nuder the name $A$. rhizophyllum in MeKen's List. Possibly it may yet be fonnd in Natal; but it is unknown to us.]

71.-A. (Darca) brachypteron, Kze.; (A. Dregeanum, Kze., is the same plant.) Moist rocks, and old trees; Inanda; Maritzburg 'Town-bill, and abundant at Umpumulo, 2,000-3,00n)ft. above sea. Kafraria, E. Trop. Afr., and Nadagasear.-Mr.

[A. (Darca) Aluccidum, Forst.: (A. odontites, R. Br.) Said in Syn. Fil. to bare been gathered by Mr. Sanderson in Natal; but it seems to be a mistake. MLr. S. knows nothing of it, and Kuln positively denies it to be a So. African plant (Fil. Afr. p. 203.)]

72.-A. (Durea) rutafolium, Kze.; (Conopteris, Berg., Darea, J. Sm., as also A. stans, Kzo., Can. furcata, Berg, Aspl.furcatum, J. Sm., Durca fureata, Willd.) On trees, shaded roeks and throughout bush in most parts of the Colony. 'Throughout So. Africa, Zambezilaud, Masc. Is., Himalayas, Ceylon, Japan and Fiji.-C.M.

73.-A. (Darea) Thunbergii, Kze.; (Cenopteris auriculata, 'Thbo., D.trea, Seh].) Near streamlets in bush; abundant at Umpumulo, and Maritzburg Townhill ; barely appears at Iuanda; 2,000-3,000ft. above sea. In Natal only.-M.

74.-A. (Athyrium) Filir-fiemina, Beruh.; ("Lady Fern.) In margins of bush (not beside water,) on 
the heights abore Karkloof and Riet Vlei. Gathered also by Sir H. Barkly in Basutolind. Not known in Cape. Cosmopolitan.-U.

75.-A. (Athy ) schimperi. A. Br. ; (formerly mistaken for $A$. Fillix-formina. but at once distinguished from it by its creeping i bizome.) About cxposed but damp rocks in Nottingham and Karkloof districts; and in bush at Cathkin, fine; 4,00n-5,000ft abore sea. Appears at Umpunulo, $2,500 \mathrm{ft}$. Abyssinia, - U.

70.-A. (Allyyr.) aspidivides. Schl. ; Allantodia, Kze., Aspid. scondicinum. Willd., Athyrium laxum, P.\& R.. as shown in Rawson Herbarinm) Ve"y wet f)'aces in shade; Kranskop ; Noodsberg; Umpumnlo; Karkloof to Richmond Throughout So. Africa. Fermando Po, Masc. Is., Neilgherries, Sandwich Is., and Ecuador.-M.U

[Actiniopteris radiata, Link.; (Bleehnum radiatum, Pr.) Gathered by Mr. Todd in the Transwaal; is probably to be found also in the nor thern prortion of Nital. Lady Barkly gires Griqualand West as a h.ibitut. Zambezi, Abyssinia, Erypt, Angola, Masc. Is., Arabia, Ceylon, India, Ava.]

\section{DIDYMOCHLANA.}

77.-D. Tunulatu, Desv.; (D. dimidiata, Kze.) Thet shady places; Inanda; Maritzburg 'Town-hill; Conpumulo ; 2,(0)(3)-3100ft. abore sea. IV. Trop. Afr., Mrisc Is., MTalay Penins. and Is., Fiji, and Trop. America. Kulm regards our plant as a var. (dimidiata) of D. lumulata, and confines it to Natal. - M.

\section{ASPIDIUM.}

78.-A. (Polystichum) aruleatum, Sw.; ( Polystichum anqulare. Pr., but not P. pungens, P. \& R as quoted lure by Knhn. It is the British "Prickly shield Frru.') Abu“dant in bush ; from Maritzburg Townhili and Karkloof to the Drakensberg, 3,000-7,000ft. ntwive sea. One solitary plant has been seen on the Little Noodsberg. E. Prov. Cape. Cosmopolitan.-U.

7!1.-A. (Pnlyst.) Tuctunsum, Kze ; (Polystichum lu. $110.5 \mathrm{~m}, \mathrm{P}$. \& $\mathrm{R}$., regarded at kiew as only a var. of No. 78.) Bush, not usnally beside water ; Maritzburg 'T'own-hill, and Nottirgham. 3,0)(0.4,000ft. E. Pruv. Cape, and Kafraria.-U.

s'l.-A. (Polyst.) puncens, Kaulf. : (Pol.yst. pungens, $P$ and li., distinguished at once from No. 78 liy its ruming rhizome.) In bush, but not beside water; 
common from Inanda to the Drakensberg, 2,000. 5,00 ift. above sea. 'I'hronghont So. Africa.-ML.U.

81.-A. (Polyst.) Capene, Willd.: (A. eoriaceum, Sir., Polyst. coriuceum, P. \& R ) Moist roelis, chiefly in the open; about 3,000ft. abore sea. Intshnuga Cutting; Grt. Noodsberg; Irafamasi; Naritzburg Town-hill. Barely ajpear's at Umpumulo. Throughont So. Afriea. Masc. Is., Austr, and N. Zealaud; Polynesia; from Cuba to Patagonia.-M.

82.-A. (Polyst.) aristutum, Sw.; (the entry of $A$. frondosum, Lowe, in MeKen's List was a mistalie.) Margins of streamlets in bush: Maritzburg Townhill; sonrces of the Umlas; Nottingham ; Karkloof. Not in Cape. From Japan and Himalayas to Ceylon, Norfolk Is., Fiji, Samoa, N. So. Wales. Zambezi (Knhn.) - U.

83.-A. (Cyrtomium) fulcutum, Sw.; (Aspit. anomophyllum, Kuhn ) In drier parts of bush, 3,000-5,000ft. abore sea. Minitzburgr 'Town-hill; Umpumulo (rare); Riet V'lei; Nottingham; ('athlin. E. Prov. Cape, Transralal, Madigascar. Himalayas, Cbinı, Japan, and Sandwich Is.-U.

\section{NEPHRODICM.}

84.-W. (Lastrea) albo-punctutum. Desv.; (Arthropteris, J.Sm.. A.spidium leucosticton, Ḱze.) Open rocks; about two miles W. of the Inanda, and immediately below Insusi Waterfall, only; 2,000ft. abore sea. WV. 'Tiop. Afr., Masc. Is., Fiji.-MI.

85.- $\Lambda^{T}$. (Last.) Bergianum, Baker ; (Lastrea patens, P. \& R.) Beside almost ercry streamlet from the coast to Maritzbung Town-hill, and eren beyond, both in the open and in shade; very large, with imner pinnules remarkably dereloped in Seven-Mite-Bush, Upper Umkomas. 'Thronghout S. Afriea. $-\mathbf{N}$.

Aspid. Gucinzianum, Mett.; (A. Natalense, Fée) - differs by the presenee of a gland at the base of the pinnæo beneath;' but this gland seems to us to be an almost in rariable feature of the plant. At all erents, we cannot distinguish betreen the two.

86.-N. (Lust.) Thelypteris. Desr.; (Polypodium, I. the 'Marsh-fern' of Gr. Br.) In marshes; rery common on the eoast, but extending to the far uplands. 'Throughout So. Africa. Anyola, Europe. N. Amerien, N. Zealand, Japan, Ammrland, Cashmere. Kuhn gives ou" plant as Aspid Thelypteris, Sw., rar. squesmuligcrum. Schl., and confiues it to the Cape, Natal and N. Zealand.-N. 
87.-1. (Last.) athamanticum, Hk.; (Aspid.atham. Kze, Lastrer atham. P. \& R. L. Plantii, Mloore.) In the open, often in ant-bear holes; in most parts of the Colong. It is the Intiomoliomo of the Kafirs, and a vermifuge like its eongener the 'Nale Fern' of Grt. Brit. Rare in Cape. Angola, Magalisberg.-N.

88.-. N. (Tast.) inaquale, IKk.; (Aspidium, Sehl.) In moist (not wet) places nearly ererywhere orer the Colony, the larger suecimens haring a rery different appearance from the smaller. Throughout So. Afr. Trop. Afr., and Mase. Is.-M.U.

Knln crises Aspidium pentugonum, (Lastrea pentagona, P. \& R.) as a different species; but small specimens in the Rawson Herbarinm Baliel takes to be ' $N$. Filix-mas, Rich., or perbaps $N$. incequale, Hk.' They seem to us to be only the smaller form of the latter.

89. -N. ( Last.) Buchanani, Baker; (Lastrea crinita. Boirin. 'This name, if the plant be the same, is deseriptive; for, while growinn, the fronds are eorered with long hairs, strikingly transparent in the sunlight, but quiekly disappearing in tbe proeess of drying.) Close beside running water in shade, about 4,00) ft. above sen; first diseovered at Nottingham, afterwards found on Zwartkop; Karkloof Heights; and in Griqualand West on the heights at Haneock's Drift, Unzinkulu. Bourbon.-U.

30.-N. (Last.) catopteron, Hk. ; (Aspid. lanuginosum, Kuhn., A. odoratum, Mett.) Near streamlets, in bush: Inanda; Noodsberg; Umpumulo (eommon); Maritzburg 'T'own-hill ; Riehmond. Found by Lady Barkly at George and the Kilysna, Cape. Guinea Coast, and Mase. Is.-M.U.

91.--N. unitum, R. Br. var. propinquum, R. Br.; (Aspid. unitum, var. glabra, Mott., N. Ecklonionum, P. \& R., A. Ecklonii, Kze.) In marshes and wet places, in the open; eommon from the evast to Um. pumulo and Maritzburg. Thronghout So. Afr. Cosmopolitan. Kubn gires P. and R.'s Neplerodium Plantianum, as a distinct speeies from this, but speeimens in the Raws. Horb. prove them to be the same.-C.M.

92.-N. molle, Desv. (Aspid. molle, Sw., Folyp. purusiticum, L.) Moist and shady places; on the const. nud common from Inanda to Uinpumulo. 'I'ransvanl. Cosmopolitan. What we take to be only a luxuriant form of this plant, found in tho bush- 
8wamp at head of Bay of Natal, was once thonght by Mr Baker to be . . elulum, Bojer (a Mauritins plant); but slecimens of the same sent at a later date were adjudged by him to our No. 92. In this view we concul.-C.IM.

Kuhn gives a var. violascens Mett. as orcurring frecuently in Africa, but the purplish rachis (whieh probably occasioned the names seems to depend entirely upon the degree of the phant's exposure to light.

\section{NEPHROLEPIS.}

93.- $N$. acula, Pr.; (N. biserratu, Schott, Aspid. biserratum, and aculum, Sw. Aspid. splendens. Willd.) Abundant in openings in the bush swamp at head of Bay, and a few plants on roeks by Palmier \& Nonoti, only. 'I'ropies, nearly over the world.-c.

\section{OLEANDRA.}

94.-O. articulata Pr.; (Aspid. arlie. Sw., O. distentu. and densifron., Kze.; O 'T'rouarsiana, P'r.) On roeks; ralying much in appcarance according as exposed or shaded. in rich suil or poor: Kranskloof; Intshanga; Mnnrizburg 'lown hill; and from Inanda

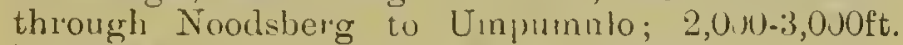
Transwal, W. 'I'rop. Afi., Mase. Is.-M.

\section{POLPODIUM.}

95.-P. (Phegopteris) oblusilobum, Dess.; (Aspid. Desvuuxii, Met1., I'vlyp. liergiunum. I' \& R., as shown by the Rawson Herbarium, but which Kuhn bas mistahen for their Aspid. liergianum.) About shady streamlets; c mmon fiom Umpumulo to SerenMile-Bush on the Upper Umkomas. Nlas. Is., Fernando Po and Cameroons [Mr. Bal er was once disposed to put this plant $n$ ith Nephrodium conlerminum, Desv (a common American plints. on acconnt of a rery minute incolucre which may be detected on the plant vccasionally; but. in the late kd. of . yn Fil. our No. 95 is reanined as a Natal species; and, evidently, with reason; for the involucre. even whon visible (which is seldom), is strict.ly rndimentary, and the sori. as a whole, show all the mregulanity, in shape and size, of other speeies of Phergin leris. $N$. microbasis. Baker, '2n African representatise of conterminum, it seems, has a 'densely bristly' involucre.]-U.M.

96.-1'. (Goniopleris) proliferum, Pr.; (Ampelopteris, Kze.) Moist open ground from coast to 1,000ft. 
above sea; near Umgeni Brickfields, and half-rray thenee to llurban; banks of Umhloti near 'Todd's Mine, and of the Impisi near to 'Tngela Zambeziland, Mauritius, Angola, N. Indıa to S. China, Philippines, Ner Caledonia, N. Australia - C.

97.-P. (Goniopt.) unitum, Hk.; (Phegupteris, Mett., Gymnogramme, Kze. Goniopteris syluntira, P. \& R.) Streamlets in busli; Inanda; Great Noods. berg; Maritzburg 'Torn-litl; Fort Buekingham; eommon at Umpimulo; 2.100-3,000ft. abore sea. Cameroons - M.

99-_ P. villgere, L.; ('Cominon Polypody') Moist shady plaees; rare in Natal; bush at Lynedoeh, rocks near Boston, and at Norton's, liet Vlei, only. 4,000ft. ahore sea. 'I'hroughont Sonth Africa and Europe; 'Turkey, Japan, Barbary States. Madeira, Azores, Canadia, and thenee to California and Mexieo.-U.

99.-P. (Goniophlelium) cnsiforme, Thbg.; (Marginaria, P. \& K.. Phlehodium. J. Sm) Habitat unknown to ns: gathered by Gue nzius on the Tugela. and by Plant. Forests of Swellendam and Knysna, Cape-C. probably.

100.-P. (Gonioph.) incinum, Sw.; (Polyp Feklonis, P. \& R.) On trees; Cowie's-hill to IJmpumnlo, rare: Maritzburg upwards, common. Knysmi, and E. Prov. Cape, Zambeziland, Ohio to Chili. - 'M.

101.-P. ( Viphobolns) Africanum, Mett. On trees; Toolsey's D rift. 'I'ucrela; Üpper Umhlali; head waters of Omoa; Dileomb's Kop, Oakford; ravines at Spring Vale, Uinkomas. Kafraria. Zambeziland, Angola, and Guinea Coast.-C.

102. - P. (Phymatodes) Schraderi, Mett.; ( P. clongatum. Sehr, Phymatodes elongata, P \& R.) Ontrees and moist roeks; orer the Colony. Kuysna and $\mathrm{E}$. Prov., Cape - $\mathbf{N}$.

103 - P. (Phym.) lineare, 'l'hbg. ; (Polyp. Gucinzii, Nett.) Habitat not known to us. Sind to hare been collected in Nutal by Gucinzins. Katraria. Mase. Is., Angola, Fermando Po; N. India and Japan, to Ceylon and the Malay Islinds.

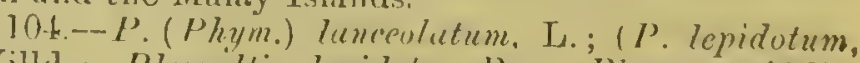
Willd.; Ploopellis lepidutu, P'r.; Pleop. ensifolia, Hk.) On trees, and moist shady rocks: barely appearing at Inanda, bat abmulant from Maritzburg to the Draliensberg; 2,000-5,000it. $\Lambda$ singular pin- 
nate form has been gathered in Seven-Mile-Bush, Upper Umkomas, and on the heights near York. Throughout So. and 'I'rop. Africa; Mase. Is, Neilgherries, Sandwich Is., and Cen. and So. America. -U.M.

105.-P (Phym.) lycopodioides. L. : (Pleopcltis lyc., P. \& R., Anapeltis, J. Sm.; P. Muckenii, Baker.) Trees and loeks; eominon about coast to Inanda and Kruisfontein,'T'ongat; but not on the higher uplands. WV. 'Trop. Afr., Mase. Is., Java, Samdwich Is., Cuba and Mexico to Peru and So. Brazil.-C.

106.-P. (Phym ) normale, Don. ; (P. Pappci, Mett.) On roeks, and in moist parts of bush; rare: has been seen on Mraritzburg 'lown-hill; a few plants at Deepdene, Riebmond; more plentiful in Seren-Mile-Bush, Upper Umkomas. Kafraria - U.

107.-P. (Phym.) irioides. Iam.; (P. punctatum, Sw., Acrostichum punct., L.) Un trees, and shaded roeks; eommon along the coast, and to about $500 \mathrm{ft}$. above sea. Mouth of St. John's Rirer, Kafraria (Sir H. Barkly), but not in Cape. Over all 'Trop. Afr. ; Mrasc. Is.; $\mathrm{N}$ India and Chuzan to Fiji ; Isle of Pines and N. So. Wales. - C.

108. - P. Phymatodes, L. ; (Phym.vulgaris, P.\& R., Drynaria vulgaris, J. Sın.) Only in eonst bush, often on trees. Apparently throughout the Tropius.-C.

\section{NOTHOCHLENA.}

109.-N. inaqualis, Kze.; (Cheilanthes, Mett.) Fissures of precipitons roeks, with northern exposure; on a ridge to the nortb of Balutsbi's Kraal, Inanda; and in a similar situation at Umpumulo, 2,000 2,500ft. abore sea. 'Transraal, and Angola.-M.

I10.-N. Eckloniana, Kze.; (Cheilunthes, Mett.) Open roeky places, from Noodsberg and Riebmond to ('athkin, 3,000-5,000ft. above sea. 'Throughout So. Afriea.-U.

111.- N. Buchanani, Baker. At base of damp roeks with southern exposure; Inanda; Grt. Noodsberg; Iskoti in Little Noodsberg; and Umpumulo, 2,000-3,000ft. abore sea. Natal only. - II.

\section{GYMIYOGRAMIME.}

112.-G. (Leptogramme) Tottu, Seh1.; (Grammitis Tutla, Pr., Gymn. Louci, Hk. \& Gr., Phegopteris Totta, Mett.) Close by streamlets in bush: Fort Buekingham; Karkloof; Mlaritzburg 'Town-hill ; Nottingham, 3,000-4,000ft. Thronghout So. Africa. W. 'I'rop. 
Afr and Abyssinia; Madeina, Azores, India. Ceylon, Jara, Hougliong. Japam, Corea.--U.

11:- -r. coidulu, Schl.; (Acrontichnm, Thbe.. Asplenium. Sw.. Feterach rordutu and rapensis, L.\& R.) On rocks, and in bush: nen spring Vale on the Umhomas: Umlas Upper Drift : abore Bishopstowe ; betreen Bothas-hill and Umireni Unpmmulo in deep northern racines; and abundant abont Catlskin; 2,0:10-5,100/t 'lhronghom So. Africa; Maralisberg, Angola. St. Helena, Bourbon-M.U.

114.-Cr. (Ceropteris) argentea, Mett.; (G. eonspersa, Kze, G roser. Desr., G firinosa. Bujer. "Silver Fern.'। Abont rocks in bush; rare at Umpunnulo; common on Nrodsbergs; rery fine and abundant on Isangnan. 3,000ft above sea. 'I'riansraal, and II ise Is.-M.

1Ita-Gr.aurea, Desr.; ("Golden F'ern.') A rariety of the foregroing, with yellow powder, but mole rare in Natal. Ocenrs besile Iskoti on Little Noorlsberg, and wis gatliened by MeKen in the lill-bush on the north side of Uinbloti, Inanda. Free State and 'Tumsraal.-M.

115.-L(r. (Sellignea) lanceolala, Hk.; (Grammitis, Sw.; Pulypodium Lon.yramme, Mett.; Grammitis coriuced, kif.) On trees and damp roeks; appears at Noodsberg ind Umpumulo; from Greytown to the Drakensberg, eommon; $2,5005,000 \mathrm{ft}$. Guinea C'oast, Abyssinia, Mase. Is., Ceylon, India, China, Japan, Fiji, Samon.-U.M.

\section{VITTARIA.}

116.-T. (Treniopsis) lineata, Sw.; ( $T$. isoëlifulia, Bory, I. lenera and surmentosa, Féc, Ploropsis anguslifolia, P. \& R.) On damp rocks and old trees; sparsely, from the coast to the Drakensberg. T'hroughout So. Afriea. Zambezi, Guinea Coast. Mase. Is. India, Malacca, Japan, West Indies to

\section{ACROSTICILM.}

11:-A. (Elaphoglossum) conforme, Sw.; (A, angus latum, Schr., A. oblongum, Desv., Olfervia cingustata and conformis, P. \& R.) Kranskloof; through Inanda and Noodsberg to Urnpummlo, and from this line to the Drakeusberg, common; $1.500-4,000 \mathrm{ft}$. abore sea. 'Thromghont so. Alri(an. Gininen Coast, st. Helem, Mise. Is. Ceylon, India. Inra, Quecnsland, l'olynesia, Mexieo to Briril. - M.U.

Our plant has been repentedly numed A. riscosum, Sw., at Kow; but, surely; by mistake. It does not 
agree with the deseription of the latter. or specimens from Manritius, but it does rery well agree with horh description and specimens of $\Lambda$. conforme, which is an acknowledged So. Afr. Mlant; and it is so set down by Kuhn in Fil. Afi. We therefore substitute this luanc fol A. "istosum of Vicken's List.

118.-A. (Flu, h.) lutifiolim. Sw.; (not named by Kuhn.) On rocks, usually in deep shade. Confined to a limited line of comntry, stretching from Kranskloof throuch Inner Inandia and Noodsberg to Umpmmulo. $1500-2.500 \mathrm{ft}$ abore sea. Mexico and Cuba to Brazil aud Peru.-M.

11!)-A. (E7uph) h.ybridum, Bory : (Olfersiu, Pr.) On moist shatd; locks: neall Peel's, Unilas ; Marit\%burs 'lown hill (a few plants); aloundant on the К:ıPkloof huights; $3.0005,000$ ft. eleration. Masc. Is, WV. 'Lrop Afr, Mexico to Brazil.-U.

1:).-A. (Elaph) Auberlii, Dess. On damp rocks, and fallen trecs; near l'eel's, Umlas; and in Kallikof Bush. Yambeziland, Bourbon, Fernando P'o, Vennzucla, Griatemalir.-U.

121.-A. (E7uph.) spathutatum, Bory; (A. pilased. frilles, l'r.) On moist rocks open to the sontle from siven-Mile-13ush, throngh Nottumgam to Karlinof range; 4.000-5,000ft. abore sen. Masc. Is., Ceylon; C'uba and Mexico, to Brazil and Peru.-U.

12.2.-A. (Stenochlenu) tenuifulium, Baker; (Polybotrya tenuifutia. Kubn. Stemselt.ena Deyeriana, P. \& R., Acr. Heyeritum. Hk.) 'T'ree-climber' common in wet bush at the coast, reaching to Inanda and L'msuudusi. 2,000tt. abore sea. East. 'Ilop. Afr. and Masc. Is.-C.

123-A. (Chrysodium) aureum. C.; (Chrysod rul. gare, Fée, Arrostichum inaquale, Willd) At the erlge "of high water, all round the Bay of Natal, and neil" Tmhlali. Algoa Bay, Nasc. Is. and Trop. Coasts generally.-C.

\section{OSMUNDA.}

12.1.-O. regatis, L. ("Royal Fern.) Wet open places: common on the const: and frecrnent thence to the Dinkensberg. Cosmopolitan.-N.

TODEA.

125.-T. barbara, Moore; (Amrostichum, J. Os: munde. 'I'bber, Todea Africena, Willd.) By strenms and rills; common from the Palmiet to Tnandir, Noodsberg and Umpumulo, 2,500ft. Throughont so.

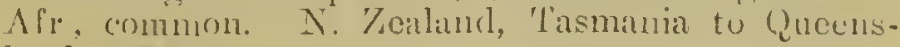
lanm. - NI.C. 
SCHI\%.1.

126 -S. temellu, Kif. B side watront Inyangwinc, lintwalnmi (gathered by Ilchen.) 'l'hroughum șu. Alicion-C.

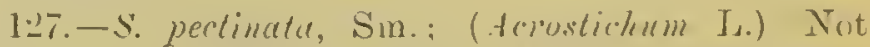
known to us, but gatlered in Natal by Gueinzins, leste Kinhn. Cape; st. Helena.

\section{A.VIIIA.}

128-A. Drepeanu, Kze. Drier parts of Imsli; Palmiet; Inandir at Umhloti; Noodsberg ; somtheru ravinos at Umpumulo; and abundant on Mlatitzburar 'Iowr-hill. Kafratia.-N.

MUIIRIA.

120.-.T. Cafpiorum, Dess. (Pulypolimm, L., Osmande thurifiage, Bors, Mohria thurifienge, sis.) I inmp open slopes, often abont the margin of bush; over all the Colony. 'T'hroughont So. Alrica; Masc. Is. $-N$.

M.IRATTI.L.

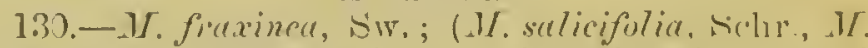
Dregeana and Nalulensis, P'r. Onl plint is retnincel by Kulu as a distinct species from $M$. firt.xinen, $5 \mathrm{~m}$.) Ravines; from Umbilo lalls and Field's-hill, 1 lrough Inanda, to Umpumulo, and thence to Maritriming 'T'own-hill. George, 'L'zitsiliamına Forest, Carpe. 'l'rop. Alr., Mase. Is., India, Philippines, Malaeens, P’olynesia, N. Zealand, Queensland, Nortolk lsland.-ME. OPHOGLOSSUM .

131.-O. capense, Schl.; (O. murlicumle, var. ceprusc Mett.) Sandy banks, about Durban. Karroo Deserts, at Ulifant's River, Cape. We prefer, with Kulun, regarding this as a distinet species from $O$ rulyatum L., with whieh it is jomed in sym. Fil. It is an elonrated, slender, orange-tinted plint, compined with No. 132 , and not so viriable - C.

132.- O. reticututum, L. In the open fields. ()ften on slopes alsout the upper margins of busls. ()rer most of the Colony. 'Thromghont So. Ml'. Cosmupolitan.- $\mathbf{N}$.

\section{EQTiSRTH.}

F. ramosissimum, Dusf. Umpmmulo: [ys's Doonus Sipruil Drift. Cosmopolitin.

IS COP()DUM.

L. Cavolinianum, L.; (I. repens. Sw.) Open wot. places: lilat at head of Bay of Natul ; Lanula hupglits:

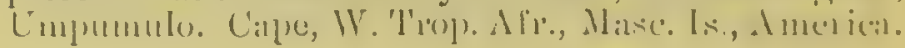


T. rernum, I. Wet open stony placer, and sides of ditches; common alsut the cosst, l)ubalu blit to Field's.hill, Lnanclis and Unupunnlo. Capse. 'I'ropical worlel.

L. cluveluu, L. var. inflexu, Spring. (Lyc. infexuu, Siv.) Open wet elayey slopes; Lnanda ; Umpumulo; Maritzburg 'Tuwn-hill. Cape, and Masc. Is.

L. gridioides; L. (L. pinifutiun. IIf., I. funiculosum, Lam.) On rocks and trees, iu pendulous rasses; but nowlierc common. Inandil; Umpmmulo; Masritzburer hills; Richmond; Karkloot. Cape. Masc. Is.

A Lycopodium with longer'leaves, and not glumeous like the last is found on old trees in Kiukluof Busl. Is it a valiety? or new ?

I. Suurulus, Lam. On rocks in Nottingham Bush, and Lynedoch. Cape. Cumeroons, Mauritis, Ceutr. and So. America.

I. verticillatum, L, On troes in Mitritzburg and Unupunulo Bush. Bumbon. P'olynesiand America.

PSILOTUM.

P. triquelium, Sw. On old trees, on the coast; rare: bush-swanp) at head of the Bay. 'T'opics.

\section{SLLAGINELLA.}

S. denticuluta, Link. (1,yropodium drut. $\mathrm{I}_{1}$ ) $\mathrm{In}_{1}$ damp parts of bush, in most parts of the Colony. Algeria, Madeira, Canaries, Lurope, Asia.

S. Irrausiana, Al. Br. On wet rocks in bush, in most parts of the Colony. Cape, IV. 'I'rop. Afr., Madeira, Kilimandja.o. Europe.

s. pumilu, Spring. (L.yc. pygmaum, Klf.) 'Cape and Natal,' Kubn. Not knowil to us.

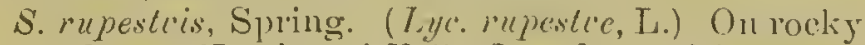
glound near Umzinyati Fialls, luanda. Africa generally. Asia, America.

\section{M.ITSIr.IA.}

M. Capensis, Al. Bu.; (Marvitia quadifulia, var., Kze.) Near Foxhill, Maritzhurg; in a natural pond on Little Noodsbelg; pouls on Durluan flat; ravine at Coedmore. C'ape.

Noтe.--To indicate the districts to which the species severally brlong, we hare appended the letters C. II. L and $\mathrm{L}$. to denote, respectively, Co:sst, 
Midland. Cpland, and Natul generally. The chief ab) reviations of Authors numes ate the following, viz. :-

$\Lambda$ it. ......Aiton.

J3ernh... T3ernhareli.

I3r. ....... Brown.

('ar....... Cirranilles.

J)er. ...llesraux.

Forsk.... Furskahl.

Forst. ... Forster.

(ierre... (ierrard.

(ir:...... (irerille.

Hk. ..... Hooker.

Kit. ...... Kiulluss.

lize......Kn11\%e.

T. \& F.... Lang-dorft \& Fishor. Jab. ...... I tabcillardière.

I tam ...... Isimnarek.

Mett....... Mettenius.

I'l'......... T'resl.

Sichl...... Sehlechtendalıl.

Schr.......schurater.

Sim. ..... simith.

Spreng ... Sprengel.

sw........ Siwaltz.

'Thbe.....'Thunberar.

Willd...... Willdenow.

Althongh we hare confined onr notes, in the foregoing Tist, to that portion of Natal which is lounded by the ocean, and the three rivers-'Ingela, Mooi, and Umkonas, yet the remaining parts are probably represented pretty fully. Oul district itself naturally fills into three distinct sections, viz.:-

C., the Coast Section, extending from the sen to an elevation of about 1, oouft. 'l'o this section exclusircly beloner otr. Nos. 1:3, 17, 40, 60, 93, 96, 99, 101, $105,107,108,122,123,126,131$

M.., the Midland Section, whose central line may bo taken as stretching from Patillo's, by Botha's, through the Inanda hills, orer Grent Noodsberg to Tompumulo, say from $2,(100$ to $2,500 \mathrm{ft}$ abore the sea. 'T'le upper limit is tolerably well drawn by the higle road from Richmond to the City, and thence to Greytown. 'This Section claims exclusirely Nos. ], 3, 5, $32,21,22,23,30,32,35,43,47,48,52,62,71,73,77$, $81,81,94,97,109,111,114,118,130$.

U., the Cpland Section, whose basc-line may be taken ns rmining from Seren-Mllile-Bush on L'pper Umkomas, through Boston, Lower Nottingham dis. triet, and Karkloof, to the heights abore Greytorn, its upper limit being the 11 ooi Rirer. These limits include the ' hackbone ' of Natal, from Drakensberg to Nount West. Its cloration may be giren ronghly as 4,000 to 7, (rooft. abore the seas. 'T'o this Section helong exchusively Nos. (i, 15, 16, 1s, 20, 2.;, 31, :37, $41,51,53,51,50,61,69,71,75,78,79,8 \div, 83,89,98$, 
$100,110,112,119,120,121$. Between C. and M., and angian between $\mathrm{M}$. and $\mathrm{U}$., there is a border-land on which the sectional species orerlap and intermingle, so that it is impossible to draw an exact limit anywhere, but within the limits sperified the characteristie species of these districts are sufticiently marked.

'T'aking, next, these districts in pairs, we get two arlitional Lists. Thus orer both C. and M. stretch Nos. 14, 29, 72, 91, (12, 125. Orer 11. and U. together cxtend Nos. 9, 10,34, 42, 61, 63, 66, 80, 88, 90,113 , 117 ; and to these we wonld add Nos. $27,49,76$, as iblso Nos. 2, 11, 50, 58, 59, 70, 95, 100, 104, 115 ; the furmer of these tro sub-classes having its proper lrome in M., but stretcling more or less into U... and the latter having its proper home in U., but overlapping more or less the npper poution of $M$.

linally, the following Nos. seem to be equally at home in all the three Sections, viz.:-4, 19, 20, 333 , $36,38,39,41,45.46,56,57,67,85,86,87,102,116$, $12 k, 128,129,132$.

Arlding these rarious sectional numbers, we find that of our 132 ascertained species, C. contains 43, M. S1), and U. 75.

Tn this analysis we bave made no account of merely sporadic plants, e.g., one of No. 78 on the sonthern limit of Little Noodsberg, one of No. 20 at Umpu. mulo, one of No. 83 at Fort Buckingham, and eren a few stray plants of No. 69 (which swarms in U.) on the Great Noodsberg. But, with our present data, we hare allocated the sercral species as exactly as possibJe; and although, confessedly, this allocation is only an approximation to accuracy, it may, nerertheless, serre a good purpose by stimulating other obscrsel's to follow ont so interesting a line of enquir'y. After all, howerer, draw border-lines where re may, in Botanical as in more momentous ques. tions, doubtful characters will congregate there.

We insert the following note as indicating a probable solution of some of our difficulties. It is from one to whose long and indefatigable industry the Botany of South Eastern Africa bas been much indolited :-

My Dear Mr. Buchasax,-I obserre that, in your Rerised List, my name is repeatedly mentioned in connection with Ferns said to bare been collected by 
me, but in regard to which I ean give no information. I may be permitted to explain that, as far back as the end of 1851 and early in 1852, I spent sume months in the interior, ineluding the then eompura. tirely little known region of the Magalisberg, and eolleeted a few plants, which I sent lome to the late Sir. William Hooker, without so much as keeping duplientes or memorindum of what I scnt. Among these may have been a few I'erns, and possibly those atcributed to me by the authorities quoted log you. I regret to be unable to throw any further light ujon the matter; and, indeed, think it quite possible that ny name may have been eomected with them by mistake. Bcliere ne, ny dear Mr. Buchanau, your's, Sc., JollN SANDERSON.

Since the former portion of this pamphlet was sent to the press, Mr. Siuderson has received a packet of specinems, gathered by Mr. Ayres at Mae mae Gold lields, and which we hare examined with mueh interest. Out of 68 species, there are at least seven which we have nerer secu in Natal, but which may probably be found in the far up-lands of the Colony.

Besides $71 y m e n o p h y l l u m$ rurum, and $I I$. lineure, observe the following, viz. :-

1.- Fragments of a lirge quadri-pinuatifid Peller, ncar to $P$. consobrina, but with larger pimules, and a very broad wrinkled involnere, which, instend of shrivelling up as the sori beeome mature, spreads itself out like a fir 1 , white and full, all round tlie margrins of the lobes.

2.-Ditto of a large Asplenium, apparently near to A. polypodivides, if not a variety of it.

3.--Ditto of an Aspidium, rescmbling A. falcutum, but with pinne twice as long, not merely tootled, but eut into short lobes, sonce of whieh are again seren or eight-toothed. 'The sori are all plaeed near to the mid-rib.

1.-Ditto of a light.green Nephrorium, decply :1יpinnatifid, with bluntly ronnded lobes, every pint shortly haily, but espeeially the large, jersistent, rometimes elongated involueres. An entire frond from a very young plant secms to indiente a tripartite charaetcr.

5.-Ditto of a Sageniu, apparently very ncar to, if

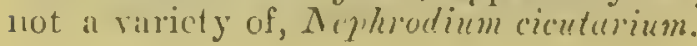

J. 13. 


. 

.

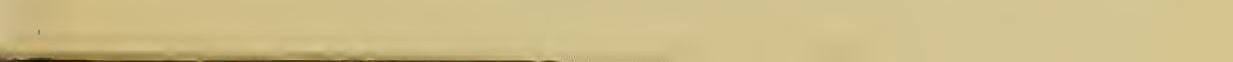










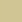

. 











